\title{
La protección al consumidor inmobiliario. Aspectos generales en el derecho colombiano*
}

\section{Juan Carlos Villalba Cuéllar ${ }^{* *}$}

Resumen: La protección al consumidor de vivienda nueva tiene matices especiales en el derecho colombiano que ameritan su estudio. El presente artículo tiene como objetivo delinear los aspectos fundamentales de la normatividad jurídica que, a la par de las normas tradicionales del derecho privado, protegen al consumidor inmobiliario en el contexto colombiano. Para tal fin, este escrito se centra en un estudio normativo con miras a identificar las principales características de este ámbito de protección en subtemas de protección al consumidor como la obligación de información, la publicidad engañosa, la obligación de garantía, las cláusulas abusivas y la responsabilidad por producto defectuoso.

Palabras clave: protección al consumidor, inmuebles, responsabilidad, información, publicidad, garantía.

Este artículo es un producto de la investigación "La responsabilidad del productor en Colombia", del Grupo de Investigación en Derecho Privado, línea de investigación "Derecho Económico y de los Negocios", del Centro de Investigaciones Jurídicas, Políticas y Sociales de la Facultad de Derecho de la Universidad Militar Nueva Granada, Bogotá, Colombia. Fecha de recepción: i6 de septiembre de 20I6. Fecha de aceptación: 8 de mayo de 20I 7. Para citar el artículo: Villalba Cuéllar, J. C., "La protección al consumidor inmobiliario, aspectos generales en el derecho colombiano", Revista de Derecho Privado, Universidad Externado de Colombia, n. ${ }^{\circ}$ 32, enero-junio de 2017, 279-313. DOI: https://doi.org/10.18601/or234366.n32.10

* Abogado. Magíster llm en Derecho Francés, Europeo e Internacional de Negocios de la Universidad Panthéon-Assas Paris ir y el Instituto de Derecho Comparado de París. Profesor e investigador, miembro de la línea de investigación en Derecho Económico y de los Negocios, grupo de Derecho Privado del Centro de Investigaciones de la Facultad de Derecho de la Universidad Militar Nueva Granada, Bogotá, Colombia. Contacto: juan.villalba@unimilitar.edu.co 


\section{Consumer Protection in Colombian Housing Industry}

Aвsтract: This article seeks to highline the fundamental aspects of the legal framework of protection to consumers according to the traditional rules of private law. The context is the Colombian housing industry. To fulfill its objective, the author will review the regulation in order to identify the main features of this area of protection as duty of information, misleading advertising, the warranty liability, unfair terms and product liability.

KeYwords: Consumer protection, real state, purchase, tort, information, advertising, warranty.

Sumario: Introducción. I. La protección precontractual al consumidor inmobiliario. A. La obligación de información. B. La publicidad engañosa. II. La protección contractual al consumidor inmobiliario. A. Garantía por calidad, idoneidad y seguridad de bienes inmuebles. B. Cláusulas abusivas. C. Responsabilidad por bienes inmuebles defectuosos. Conclusiones. Bibliografía.

\section{Introducción}

En el derecho de la protección al consumidor es común encontrarse con una normatividad general que crea un régimen tuitivo a favor de la parte débil de la relación de consumo, y la vez con unas normas especiales que se aplican a sectores especiales del mercado con esa misma finalidad, es decir, un derecho general del consumo y un derecho especial de consumo. Igualmente sucede que en ciertos sectores productivos la aplicación de las normas de protección al consumidor adquiere unas particularidades y unos desafíos propios del sector, los cuales suscitan interrogantes a la hora de poner en práctica la norma y los mecanismos de protección. Tal es el caso del sector de la venta de bienes inmuebles, nuevos y usados, en el mercado, destinados a vivienda, al que llamaremos en este artículo sector inmobiliario. El derecho de la protección al consumidor, debido a los desarrollos legales que ha tenido en Colombia en los últimos años, juega hoy en día un papel importante en las relaciones jurídicas entre los compradores y vendedores de vivienda nueva, por lo cual debe entenderse de entrada que, además de las normas civiles y comerciales que rigen la etapa precontractual y contractual en este tipo de negocios, un jurista no puede perder de vista el régimen derivado de las normas protectoras de la parte débil, ya que desbordan las nociones de contrato y responsabilidad clásicas, afectan la carga tradicional de la prueba y, en general, contienen una serie de derogaciones del derecho común que deben ser conocidas para abordar de manera integral estos asuntos.

En igual medida, debe destacarse la importancia de este sector de la economía en la vida de las personas, ya que la adquisición de vivienda, nueva y usada, 
constituye para una gran mayoría un negocio de importancia capital, a tal punto que puede llegar a ser uno de los contratos más importantes de su vida, en el cual invierten sus ahorros, créditos a largo plazo y el fruto de su trabajo con miras a cumplir el sueño de tener vivienda propia. Para el Estado es importante asimismo implementar políticas con miras a que las personas tengan una vivienda digna, tal y como lo ordena el artículo 5 I de la Constitución Política. Esto implica que en muchos casos las personas cuenten con instrumentos judiciales de orden constitucional para hacer cumplir este mandato, por verse involucrados derechos fundamentales, cuando por ejemplo se vea afectada la dignidad humana.

Igualmente, hechos recientes como el renombrado caso del edificio Space ${ }^{\mathrm{I}}$, en la ciudad de Medellín, ponen a la orden del día el tema de la responsabilidad civil del constructor. Además, la vocación para que se vean involucrados diferentes actores en esa relación de consumo, tales como el constructor, el dueño de la obra, la fiduciaria, el asegurador y las propias autoridades locales, le da un matiz de interés al asunto. Se quiere resaltar entonces que la vivienda no es un producto como cualquier otro.

Pese al espectro tan amplio que puede adquirir el tema, este artículo se centrará en el análisis de los mecanismos legales que tiene el consumidor inmobiliario para su efectiva protección, específicamente el consumidor de vivienda nueva ${ }^{2}$. Así las cosas, vale la pena interrogarse acerca de los alcances y características del derecho de la protección al consumidor en materia inmobiliaria en Colombia. La pregunta que se plantea es la siguiente: ¿cuáles son las características y matices especiales de las normas que protegen al consumidor de vivienda nueva en el derecho colombiano? Esta pregunta es importante porque en Colombia las sanciones a las empresas constructoras y los promotores inmobiliarios por infringir las normas de protección al consumidor son frecuentes ${ }^{3}$.

I "El conjunto residencial Space fue gerenciado y construido por la constructora Lérida CDo. La construcción del conjunto residencial se llevó a cabo durante 6 etapas diferentes y las 6 etapas presentaban diferente número de pisos entre sí, siendo la última (Etapa 6) la de mayor altura, con un total de 23 pisos y 4 sótanos ( 2 Niveles de parqueadero y 2 Niveles de zona social) y fue la que presentó colapso total el i 2 de octubre de 2013. La Etapa 6 del conjunto Space, tras presentar notorios problemas estructurales, fue evacuada el día viernes i I de octubre de 20 I 3 en horas de la mañana. La observación de los problemas estructurales y posterior decisión de evacuación estuvo a cargo del Departamento Administrativo de Gestión del Riesgo de Desas-

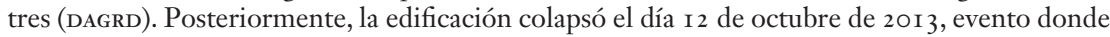
murieron I 2 personas dentro de las cuales la mayoría eran trabajadores que se encontraban realizando trabajos de intervención a la estructura del edificio": https://civil.uniandes.edu.co/ Boletin/index.php/k2/item/33-conceptouniandes

2 Vivienda nueva, según la Ley I 796 de 20I6, “[e]s aquella edificación que permite desarrollar unidades para el uso habitacional y cuyas unidades resultantes se transfieran durante el periodo de cubrimiento del amparo patrimonial de que trata la presente ley; aprobadas mediante licencia de construcción en las modalidades de obra nueva y reconstrucción".

3 Superintendencia de Industria y Comercio, Informe de sanciones segundo semestre 20 I 5, disponible en: http://www.sic.gov.co/sites/default/files/files/INFORME_sobrE_sANCIONES_IMPUESTAS_SEGUNDO_SEMESTRE_DE_2OI5.pdf 
Así mismo resulta pertinente aclarar en esta introducción los alcances de una relación de consumo en el ámbito inmobiliario. En la relación de consumo debe entenderse por consumidor inmobiliario a la persona natural o jurídica que, como destinatario final, adquiere, disfruta o utiliza un bien inmueble destinado a vivienda para satisfacer una necesidad propia, privada, familiar o doméstica y empresarial cuando no esté ligada intrínsecamente a su actividad económica (art. 5 num. 3 Ley I480 de 20 I I $)^{4}$. Señala Ariza que en el caso de los inmuebles hay por regla general una permanencia en el patrimonio del adquirente, pues no es usual, salvo en el evento de los profesionales que se dedican a comprar y vender propiedades, que un inmueble se adquiera y se transfiera inmediatamente, por lo que la noción de destino final excluye este caso, y además se deberá excluir del manto de las normas de protección al consumidor el supuesto de que el inmueble sea objeto de una finalidad económica, lo que implica su aprovechamiento para fines industriales y comerciales ${ }^{5}$, agregando que la norma colombiana condiciona que no esté intrínsecamente ligado a su actividad empresarial. Entonces, aceptando que la noción de consumidor inmobiliario puede ser más amplia, para los fines de este artículo se restringirá al futuro adquirente, al adquirente, o a quien disfrute o utilice un bien inmueble destinado a vivienda nueva.

Además, para que se configure la relación de consumo, en el otro extremo del vínculo obligacional se requiere que el vendedor o la persona que entrega el uso del inmueble destinado a vivienda lo haga de manera profesional y habitual, es decir, que en los términos de la Ley I480 de 20 i i sea considerado productor o vendedor ${ }^{6}$. Estos sujetos van a coincidir generalmente con el constructor ${ }^{7} \mathrm{y}$ el enajenador de vivienda ${ }^{8}$. Por lo tanto, cuando un particular venda un bien inmueble destinado a vivienda a otro particular, ambos con una finalidad propia, privada, familiar o doméstica, no se aplicarán las normas de protección al consumidor al contrato de compraventa, pues estaremos frente a un contrato

4 Nótese que en el derecho argentino la Ley $\mathbf{2 4 . 2 0 4}$ delimita la aplicación de la ley en su artículo I a: “c ) La adquisición de inmuebles nuevos destinados a vivienda, incluso los lotes de terreno adquiridos con el mismo fin, cuando la oferta sea pública y dirigida a persona indeterminadas".

5 Ariza, A. "Contratación inmobiliaria y defensa del consumidor", en La reforma al régimen de defensa del consumidor por Ley 26.36I, Ariel Ariza (coord.), Buenos Aires, Abeledo-Perrot, 2009, 44 .

6 "Productor: quien de manera habitual, directa o indirectamente, diseñe, produzca, fabrique, ensamble o importe productos. También se reputa productor a quien diseñe, produzca, fabrique, ensamble, o importe productos sujetos a reglamento técnico o medida sanitaria o fitosanitaria" (art. 5.9). "Proveedor o expendedor: quien de manera habitual, directa o indirectamente, ofrezca, suministre, distribuya o comercialice productos con o sin ánimo de lucro" (art. 5.I I).

7 Según la Ley I 796 de 20 r 6: "Entiéndase por constructor el profesional, persona natural o jurídica, bajo cuya responsabilidad se adelanta la construcción de vivienda nueva y que figura como constructor responsable en la licencia de construcción”.

8 Según el art. 2. ${ }^{\circ}$ num. 2 Ley r 796 de 20 r6: "Se entiende que es enajenador de vivienda nueva, quien detente la propiedad del predio según títulos de propiedad y pretenda trasladar por primera vez las unidades habitacionales". 
netamente civil. Si bien es cierto que en otros casos, como en la venta de bienes inmuebles usados, o cuando concurra la intermediación de inmobiliarias, también se puede configurar eventualmente una relación de consumo, así como en otros mecanismos para la adquisición o financiación de vivienda nueva; para el ámbito de este artículo estos temas no serán tratados.

En ese orden de ideas se abordará el estudio de las normas que protegen al consumidor inmobiliario en Colombia, identificando los límites de dicho régimen en cuanto a su aplicación y, además, sus alcances en los asuntos que cobija. Para tal fin el trabajo se dividirá en dos secciones, la protección precontractual (I), incluyendo aspectos como la obligación de información y la publicidad engañosa; y, en segundo lugar, la protección contractual (II), en la cual a su vez se abordarán como subtemas la obligación de garantía, las cláusulas abusivas y la responsabilidad por productos defectuosos. El método utilizado para el desarrollo de este artículo es la investigación jurídica con análisis normativo y hermenéutico. Dado que en materia de protección al consumidor inmobiliario no hay doctrina nacional y en el derecho comparado es escasa, la fuente predominante serán las normas que regulan el tema, así como algunas decisiones de las autoridades (administrativas y jurisdiccionales) nacionales en la materia. Se espera que este artículo contribuya a la doctrina sobre el tema y abra la puerta al estudio de la materia en el ámbito del derecho colombiano.

\section{La protección precontractual al consumidor inmobiliario}

Subraya Lorenzetti la importancia de la protección al consumidor en la fase de tratos previos o tratativas, comoquiera que allí se forma la manifestación de voluntad del consumidor, y que, dada la asimetría informativa entre el constructor y el consumidor, este último necesita una especial protección por su estado de vulnerabilidad 9 . En materia de adquisición de vivienda resulta de vital importancia dicha protección, dado que la relación precontractual de consumo entre el promotor inmobiliario o constructor y el consumidor inmobiliario tiende a ser más prolongada que en la celebración de otros contratos; esto en razón a que los constructores y promotores inmobiliarios utilizan frecuentemente mecanismos precontractuales para garantizar que los potenciales compradores queden obligados frente a la venta de las unidades habitacionales ofrecidas. Dichos mecanismos garantizan a estos oferentes la consecución de puntos de equilibrio financiero que permitan costear y ejecutar correctamente la obra, teniendo en cuenta que en la mayoría de los casos las ventas se hacen "sobre planos", es decir, como venta de cosa futura. Así, en la génesis del iter contractual entre comprador y vendedor de una unidad de vivienda nueva identificamos, desde la fase precontractual, figuras con las que se encontrará el consumidor inmobiliario,

9 Lorenzetti, R. L. Consumidores, Buenos Aires, Rubinzal Culzoni, 2009, 73 у 200. 
tales como: una factura de venta con la que normalmente el futuro comprador entrega un dinero inicial para reservar el inmueble; un contrato de fiducia inmobiliaria, dado que el constructor con frecuencia constituye una fiducia para la gestión de los recursos dedicados al proyecto inmobiliario; la promesa de contrato por medio de la cual las partes se obligan a celebrar la compraventa de un cuerpo cierto; y finalmente, el contrato de compraventa. Todas esas figuras jurídicas quedan cobijadas tanto por las normas generales y especiales del derecho privado que le son aplicables como por las normas de protección al consumidor, generales y especiales.

Lo que interesa, para los fines de este artículo, es mencionar que todos esos documentos precontractuales se rigen plenamente por las normas de protección al consumidor, las que primarán en lo que regulen frente a las normas civiles. Entonces, por ejemplo, la promesa de compraventa como contrato preparatorio de otro contrato, además de ajustarse a lo prescrito en el código civil, debe cumplir con las normas de protección al consumidor, en temas como cláusulas abusivas y demás normas de control contractual para los contratos de consumo.

En esa etapa precontractual llama también la atención la figura de la fiducia inmobiliaria, de uso frecuente en la oferta de vivienda nueva en Colombia, en la que nos detendremos brevemente para reseñar el papel que juega dicho mecanismo jurídico en los precontratos que celebran los consumidores, advirtiendo al lector que no se desviará este estudio del ámbito de la compraventa, ya que la fiducia inmobiliaria es un paso previo a la adquisición de vivienda nueva, la que en muchos casos termina con la celebración de un contrato de compraventa.

La fiducia inmobiliaria. Se trata de una figura comúnmente utilizada en el contexto colombiano para la ejecución de proyectos inmobiliarios, y de bastante utilidad en la práctica mercantil, ya que surgió como una respuesta eficiente para montar un mecanismo dirigido a garantizar la culminación de la obra y la protección jurídica de las diferentes partes involucradas en el contrato ${ }^{\mathrm{IO}}$. Se define como un contrato típico de carácter mercantil celebrado entre el constructor y la sociedad fiduciaria con la finalidad de constituir un encargo para la ejecución de un proyecto inmobiliario, y dependiendo de la voluntad de las partes esta fiducia tiene varias modalidades, pudiendo ser fiducia de preventa, de administración y pagos, de tesorería ${ }^{\mathrm{I}}$. La Superintendencia Financiera la define como un "negocio fiduciario que, en términos generales, tiene como finalidad la administración de recursos y bienes afectos a un proyecto inmobiliario o a la administración de los recursos asociados al desarrollo y ejecución de dicho proyecto, de acuerdo con las instrucciones señaladas en el contrato" ${ }^{\text {I2 }}$. A este contrato el

Rodríguez Azuero, S. Negocios fiduciarios, su significación en América Latina, Bogotá, Legis, 2005, 449 .

I I Aspectos conceptuales del negocio fiduciario en Colombia, Bogotá, cartilla editorial Legis, 20 I 5, 230.

I 2 Circular Básica Jurídica, Tít. v, Cap. Primero, num. 8 (Circular Externa n. oo7 de I996). 
futuro comprador se vincula de manera general mediante la firma de una carta de instrucciones, y, por tratarse de un contrato de carácter financiero, de este se deriva una doble relación de consumo, tanto entre el constructor (consumidor financiero) ${ }^{\mathrm{I} 3}$ y la sociedad fiduciaria, como entre el futuro comprador (consumidor financiero) y la sociedad fiduciaria; los señalamos aparte porque claramente se trata de consumidores con intereses disímiles y roles diferentes en esa relación contractual de consumo. Lo anterior indica que el futuro comprador (fideicomitente adherente) que adhiere a la fiducia inmobiliaria es un consumidor en todo el sentido de la palabra, pero un consumidor financiero en su relación jurídica con la fiduciaria, por lo que podrá prevalerse de todas las normas especiales que protegen al consumidor en el sector financiero,, tales como la Ley I 328 de 2009 y la Circular Básica Jurídica de la Superintendencia Financiera, entre otras; las cuales regulan aspectos como publicidad, deber de información, cláusulas y prácticas abusivas, etc. Igualmente se le aplicarán las normas generales de protección al consumidor en aspectos que no estén regulados en las normas especiales.

En la fiducia inmobiliaria, la fiduciaria se obliga frente al consumidor a la buena gestión de los recursos con la finalidad de alcanzar el punto de equilibrio, así como a la eventual devolución de los mismos en caso de que dichos puntos no se cumplan, obligación que las fiduciarias, además, aclaran que es de medios y no de resultado. Pero no resulta tan nítida en esta relación contractual la responsabilidad de la fiduciaria frente a los adherentes consumidores por aspectos ligados a la construcción y venta del inmueble, tales como la obligación de garantía de calidad e idoneidad del bien inmueble, regulada en la Ley i48o de 20 I y el Decreto Reglamentario I375 de 20I4. Al respecto debemos tener en cuenta que en la pro-forma de la carta de instrucciones aparece generalmente una cláusula referente a que el futuro comprador, adherente a la fiducia, entiende que aspectos como la estabilidad de la obra, la calidad de la misma, los plazos de entrega, entre otros aspectos, no están a cargo de la fiduciaria, lo cual nos da a entender que la fiduciaria se desprende de estas obligaciones. La validez de dicha mención dependerá en primer lugar del tipo de fiducia que se celebra, ya que las obligaciones de las partes se deben analizar a partir de la estructura contractual utilizada $^{\mathrm{I} 4}$, pues si esta implica un papel activo de la fiduciaria en la ejecución y construcción del inmueble se puede ver comprometida su responsabilidad.

Sin embargo, Rodríguez Azuero afirma que las modalidades de fiducia en que el fiduciario incursiona en la actividad constructora están en desuso en la

I 3 Debe acotarse que cuando el constructor actúe como fiduciante o constituyente, y no como un contratista de este, se convierte en un consumidor inmobiliario en los términos de la Ley I 328 de 2009 , que considera en su artículo 2 que consumidor financiero "[e]s todo cliente, usuario o cliente potencial de las entidades vigiladas". El fiduciante o constituyente es cliente de la fiduciaria y por lo tanto es consumidor financiero al tenor de la citada norma. En todo caso el fideicomitente es consumidor financiero.

I4 Superintendencia Financiera, Concepto 25480 de 2009. 
práctica del derecho colombiano, para dar paso a modalidades en que este tiende a tener el papel de administrador de los recursos ${ }^{15}$, lo que de antemano nos revela que la responsabilidad de la fiduciaria frente a la calidad de la obra tiende a ser nula. Esta posición se vería reforzada por un concepto de la Superintendencia Financiera de 2008 , en el que la entidad afirmó que las obligaciones de la fiduciaria en los contratos de administración de preventas inmobiliarias "no implican la garantía del cumplimiento de un fin específico pero sí el deber de actuar con el mayor grado de diligencia en su gestión y, en particular, en la administración de los recursos, por lo que responderá hasta la culpa leve" ${ }^{16}$. Recientemente, por medio de la Circular Externa n. ${ }^{\circ} \mathrm{O} 24$ de 2016, la Superintendencia Financiera expidió algunas regulaciones especiales con miras a proteger al consumidor de las fiducias inmobiliarias pero no se refirió a este tema.

Cabe señalar además que algunas modalidades de fiducia, como la "fiducia con beneficio de área", en la cual el consumidor se adhiere como "inversor" beneficiario de área, para al final del proyecto adquirir el derecho de dominio mediante una cesión del área que le corresponda a título de beneficio fiduciario, generan algunas dudas sobre la garantía de sus derechos en su doble calidad de consumidor-comprador, que se ve disimulada bajo otra calidad jurídica (adherente inversor-adquirente), y que puede ir en claro desmedro de sus derechos en el evento de un incumplimiento del constructor. Queda por ver la equivalencia de derechos de este supuesto "inversor" en relación con el rol que describe su verdadera intención negocial, que consiste en comprar vivienda nueva, es decir, el de comprador. Sin embargo, un análisis tal sobrepasa los límites de este escrito.

Para finalizar este acápite y dejando de lado esta breve referencia a la fiducia inmobiliaria, debe agregarse que existe una práctica que, aunque aislada en la promoción y venta de proyectos inmobiliarios, puede presentarse, y que consiste en la utilización por parte del constructor o del promotor inmobiliario de figuras jurídicas tendientes a liberar de responsabilidad al productor, tales como la constitución de personas jurídicas o patrimonios dedicados exclusivamente a la obra, e incluso la creación de asociaciones o corporaciones sin ánimo de lucro en las que el consumidor inmobiliario entra a participar como "asociado". En el derecho comparado estas formas de disfrazar el verdadero rol del constructor o del promotor inmobiliario como vendedor- productor se han combatido a través de la consideración de verdaderas cadenas de contratos coligados de consumo ${ }^{17}$. En consecuencia, cuando el constructor o promotor inmobiliario utiliza una se-

I 5 Rodríguez Azuero, S. Contratos bancarios, Bogotá, Legis, 20 I I, 87 I.

I6 Superintendencia Financiera, concepto 2008068357-003, de 27 de noviembre de 2008.

I 7 En Argentina se dio un caso de unos promotores inmobiliarios que vincularon a unos compradores induciéndolos a constituir un consorcio de copropietarios que a su vez los encargaba de la administración y gerencia de la obra. Ver caso Consorcio de Propietarios V + E Barrio Parque Los Hornos 3 ro vs. Cano Funes S.A., Boletín Oficial 45/52, La Plata, jueves 26 de febrero de 2004, Diario de Furisprudencia fudicial, año LXII, t. I66, n. ${ }^{\circ}$ I $3 \cdot 786$. 
rie de mecanismos jurídicos para disfrazar su verdadero rol en la compraventa de la vivienda o para exonerarse de responsabilidad, el operador jurídico encargado de la protección al consumidor debe desentrañar la verdadera finalidad de ese entramado de precontratos y contratos para identificar una verdadera relación de consumo y, en principio de la aplicación del principio pro consumatore y de la buena fe que irradian el subsistema legal de protección al consumidor, aplicar la norma tuitiva de la parte débil.

Así las cosas, aún dentro de la etapa precontractual, se examinarán dos nociones clave en materia de protección al consumidor: la obligación de información y la publicidad engañosa.

\section{A. La obligación de información}

La obligación de información, que como es sabido constituye la columna vertebral del derecho de la protección al consumidor ${ }^{18}$, resulta fundamental en las relaciones precontractuales de consumo relativas al sector inmobiliario. En aras de contextualizar la importancia de este tema, basta decir que el consumidor se ve abocado a contratar para satisfacer necesidades cotidianas en multiplicidad de sectores en los que, dada su calidad natural de profano, no es especialista; y por lo tanto tendrá que acudir a la confianza y la buena fe para obligarse en materias que no son de su experticia. Por lo tanto, esta condición de lego se constituye en la fuente de una de las asimetrías que padece el consumidor, a saber, la asimetría informativa. Dado que este no tiene los conocimientos para poder tomar decisiones acertadas e informadas, el legislador acudió a la obligación de información, a cargo del productor, como un mecanismo para restablecer parte del equilibrio perdido entre productor y consumidor, y de paso proteger el consentimiento del consumidor-contratante ${ }^{\mathrm{I} 9}$.

Por lo tanto, el consumidor inmobiliario formará su manifestación de voluntad y tomará una decisión económica con base en la información que le brinde el constructor o promotor de ventas relativa al inmueble destinado a vivienda que piensa adquirir. Para él resultará vital entonces que la información sobre aspectos esenciales del contrato, como el precio y las características objetivas del inmueble, resulte ceñida a la realidad. En consecuencia, el Estatuto de Protección al Consumidor tendrá vocación para aplicarse en materia de información brindada al consumidor inmobiliario, sobre todo en la etapa precontractual, y para tal fin actúan como normas generales los artículos 23 y siguientes de dicho Estatuto que obligan a los productores o proveedores a suministrar a los consumidores

i 8 Villalba Cuéllar, J. C. Introducción al derecho del consumo, Universidad Militar Nueva Granada, Bogotá, 2OI 2, 42 y 43 .

I9 JaZAPE, B. "El deber de información”, en Manual de derecho del consumidor, Buenos Aires, Rusconi Dante, Abeledo-Perrot, 2009, I9I. 
información clara, veraz, suficiente, oportuna, verificable, comprensible, precisa e idónea sobre los productos que ofrezcan; para el caso de este escrito, sobre los inmuebles destinados a vivienda ofrecidos en venta. En consecuencia, toda la información dada en la etapa precontractual sobre el inmueble en venta obliga al productor, así como todo engaño o inducción a error sobre el precio, el área del inmueble, las zonas comunes, las características del inmueble comprometen la responsabilidad del constructor o vendedor.

Tal importancia tiene la información precontractual al consumidor inmobiliario que, adicionalmente, la Superintendencia de Industria y Comercio (en adelante, sic) expidió la Circular Externa n. ${ }^{\circ} 6$ de 20 I 2 (hoy en día incluida en la Circular Única de esa entidad), destinada a todas las personas naturales o jurídicas que vendan y/o promocionen inmuebles destinados a vivienda, la cual tuvo como finalidad "[i]mpartir instrucciones a todas las personas naturales o jurídicas que vendan y/o promocionen inmuebles destinados a vivienda con el propósito de garantizar el respeto del derecho de los consumidores a recibir información veraz y suficiente en relación con las características y propiedades de los bienes que se ofrecen al público”. Esta norma, que actúa como norma especial y complementaria de la Ley I480 de 20 I I, tiene el objetivo de proteger y reforzar la obligación de información a cargo del constructor y que recibe el consumidor inmobiliario, por lo que examinaremos su contenido.

Según la norma en examen, el constructor tiene a cargo la obligación de informar en la etapa de preventas, en sala de ventas y en folletos o plegables:

- Se deberá informar el área privada construida.

- Se deberá informar el área privada libre o las áreas comunes de uso exclu$\operatorname{sivo}^{20}$.

La misma Circular indica: "Lo anterior sin perjuicio de que estas puedan sufrir modificaciones como consecuencia directa de modificaciones ordenadas por la curaduría o la alcaldía competente en la expedición de la licencia de construcción”. Esto quiere decir que quedaría exonerado de responsabilidad el ven-

20 Por área privada construida debe entenderse, según el artículo 3 de la Ley 675 de 200 I: "Extensión superficiaria cubierta de cada bien privado, excluyendo los bienes comunes localizados dentro de sus linderos, de conformidad con las normas legales". Y las áreas comunes de uso exclusivo, según el artículo 22 ibídem, se definen como sigue: "Bienes comunes de uso exclusivo. Los bienes comunes no necesarios para el disfrute y goce de los bienes de dominio particular, y en general, aquellos cuyo uso comunal limitaría el libre goce y disfrute de un bien privado, tales como terrazas, cubiertas, patios interiores y retiros, podrán ser asignados de manera exclusiva a los propietarios de los bienes privados que por su localización puedan disfrutarlos. Los parqueaderos de visitantes, accesos y circulaciones y todas las zonas comunes que por su naturaleza o destino son de uso y goce general, como salones comunales y áreas de recreación y deporte, entre otros, no podrán ser objeto de uso exclusivo. Los parqueaderos destinados a los vehículos de los propietarios del edificio o conjunto podrán ser objeto de asignación al uso exclusivo de cada uno de los propietarios de bienes privados de manera equitativa, siempre y cuando dicha asignación no contraríe las normas municipales y distritales en materia de urbanización y construcción”. 
dedor si una de las autoridades locales señaladas cambiara, a través de normas de obligatorio cumplimiento, dichas áreas en el momento de la expedición de la licencia de construcción.

Además, la Circular de 2012 establece otra información obligatoria:

- Cuando los parqueaderos de los propietarios estén ubicados en áreas comunes de uso exclusivo, se deberá informar a los consumidores que, una vez constituida la propiedad horizontal, la asamblea de copropietarios, con la decisión de más del 70\% del coeficiente de la copropiedad, podrá modificar la destinación de las áreas comunes de uso exclusivo.

- Se deberá informar si el proyecto que se va a construir es o no por etapas.

- Se deberá informar el valor aproximado (estimado) de la cuota de administración.

- Se deberá informar el estrato socioeconómico que tendrá el inmueble (estrato que podrá estar sujeto a modificación por parte del respectivo municipio o distrito).

- Se deberán informar las características de las zonas de parqueo.

- Se deberá informar, de manera general, las características de los muebles y equipos que se van a entregar y el tipo y calidad de los acabados.

- En caso de que el proyecto se realice por etapas, se deberá indicar claramente qué zonas comunes se entregarán con cada etapa y el estimado de cuándo se desarrollarán las etapas posteriores, sin perjuicio de que las fechas propuestas puedan variar.

Se observa entonces cómo la norma procura que el consumidor reciba información completa sobre aspectos que resultan relevantes, respecto de los cuales además la casuística demuestra que han sido objeto de disputas entre los consumidores y los vendedores de los inmuebles y de los proyectos inmobiliarios. En efecto, las investigaciones que ha adelantado la sIc en contra de algunas constructoras demuestran que en temas como la extensión de las áreas construidas, las características ofrecidas, los acabados, las zonas comunes ofrecidas, y sobre todo el cumplimiento en la entrega de los inmuebles, existen frecuentemente infracciones a las normas de protección al consumidor por parte de los vendedores de inmuebles destinados a vivienda ${ }^{21}$. Los denominados "apartamentos modelo" o "casas modelo", es decir, las réplicas de la unidad residencial que, adjuntas a las salas de ventas de los proyectos inmobiliarios, los vendedores crean y decoran para que los futuros compradores las visiten y se hagan una idea del inmueble, también hacen parte de la información brindada a los consumidores y comprometen la responsabilidad del vendedor. Con respecto a la modificación de las áreas que comprende el inmueble, informadas previamente al consumidor, la sIc,

2 I Universidad Sergio Arboleda, Superintendencia de Industria y Comercio y Red Nacional de Protección al Consumidor, Documento técnico: análisis de las problemáticas de los consumidores del sector de la construcción, Bogotá, 2016. 
en concepto de 20 I $_{5}$, dijo que la modificación posterior de dichas áreas por orden de autoridades como la alcaldía o las curadurías urbanas debe ser informada debidamente al consumidor, quien debe poder aceptarlas o tener la posibilidad de solicitar la resolución del contrato ${ }^{22}$. En realidad esta obligación de información se extiende a cualquier eventualidad en que el constructor deba modificar las áreas o características del inmueble, tanto en la etapa precontractual como en la contractual.

Ha de tenerse en cuenta que en este sector los consumidores no toman decisiones de consumo con base en la sola publicidad, ya que nadie toma la decisión de compra de un inmueble con la sola confrontación de una pieza publicitaria. Por el contrario, en todos los casos el consumidor buscará mayor información, a través de la consulta a la página web y también acudiendo a la sala de ventas de la constructora, donde obtendrá mayor información de las características del inmueble, lo que determinará en alto grado la formación de su voluntad, con el acceso, por ejemplo, a maquetas, planos, apartamentos modelo, videos representativos del inmueble (visitas virtuales), entre otros. Se espera por lo tanto que la información brindada en todas esas fases de búsqueda que emprende el consumidor sea protegida por la buena fe y la lealtad que deben primar en la etapa precontractual, de tal modo que la información brindada sea veraz y coincidente con la realidad, y así no se vulneren las expectativas legítimas del consumidor. Por el contrario, si la información brindada a través de vallas, pancartas, folletos, maquetas, páginas web, etc., luego no concuerda con la realidad del inmueble o proyecto inmobiliario recibido, se estará claramente frente a una infracción a las normas de protección al consumidor.

Así las cosas, la información contenida en la publicidad de los proyectos inmobiliarios se torna relevante en la etapa precontractual, y por lo tanto obliga al vendedor. Además, en la práctica puede ocurrir que esta información sea deficiente en su presentación a los consumidores, lo que aumenta el riesgo de que se convierta en engañosa. Es claro entonces que en este ámbito del comercio la información y la publicidad engañosa están estrechamente vinculadas, más que en otros sectores, tal y como lo veremos a continuación.

\section{B. La publicidad engañosa}

En la sociedad actual, la publicidad es el mecanismo por excelencia a través del cual los productores y proveedores promocionan sus productos y servicios en el mercado frente a los consumidores. De acuerdo a la normativa de protección al consumidor, la publicidad es fuente de obligaciones y las menciones informativas (objetivas) contenidas en las piezas publicitarias se incorporan al contrato (art. 29 Ley I480 de 20 I I), figura que la doctrina ha denominado "integración

22 Superintendencia de Industria y Comercio, Concepto I 524 I I 96 de 24 de noviembre de 20 I 5. 
publicitaria" ${ }^{23}$. Además, la búsqueda de la transparencia en el mercado, de la lealtad y el respeto por la confianza en las relaciones precontractuales de consumo, justifica un control de la veracidad de las afirmaciones incluidas en pautas publicitarias.

La publicidad engañosa es una práctica abusiva de comercio de ocurrencia frecuente en las relaciones de mercado. Será publicidad engañosa, según la Ley I 480 de 20 I I, "aquella cuyo mensaje no corresponda a la realidad o sea insuficiente, de manera que induzca o pueda inducir a error, engaño o confusión" (art. I3). En materia de relaciones precontractuales de consumo en el sector inmobiliario, la publicidad engañosa se configura con relativa frecuencia, dado que en las piezas publicitarias los vendedores de los inmuebles destinados a vivienda incluyen información, es decir, descripciones o menciones atinentes a las características objetivas de los mismos, tales como áreas construidas, fotos o imágenes de la apariencia del inmueble o del conjunto del proyecto inmobiliario, fotos o imágenes de las zonas comunes y descripción de las mismas, entre otras. Cuando esta información no corresponde a la realidad o simplemente induce a error al consumidor porque no es clara, es insuficiente o ambigua, se configura la publicidad engañosa. Es por ello que la publicidad en el sector inmobiliario tiene como característica un alto grado de objetividad, al incluir altas dosis de información, y por el contrario, en este sector del comercio es menos frecuente que los comerciantes acudan a la publicidad meramente sugestiva, y mucho menos a aquella hiperbólica en la cual se ponderan exageradamente los productos. En efecto, los constructores promocionan y ofertan bienes frente a los cuales los consumidores tienen unas expectativas reales y necesitan el mayor grado de información posible, y este factor aumenta claramente el riesgo de incurrir en publicidad engañosa. Un consumidor inmobiliario no espera en la publicidad expresiones de tipo subjetivo como "viva en un bosque encantado", más bien espera que le informen sobre áreas del inmueble, distribución del espacio construido, acabados, zonas comunes, etc. Es por esto que los constructores utilizan con mayor frecuencia la publicidad que se difunde por medios que les permiten incluir información, como folletos, vallas, pancartas, revistas o páginas web propias o especializadas en la promoción de vivienda nueva, entre otros. Así, a diferencia del caso de otros productos de uso común, resulta claro que el consumidor o potencial consumidor de vivienda nueva, más que esperar las ofertas, en muchos casos las buscará él mismo en el mercado, les dedicará más tiempo y se fijará más en la información que le brinden. Todo dentro de los límites del comportamiento normal de un consumidor medio, valga la aclaración.

23 Miranda, L. M. y Paniagua Zurera, M., "La protección de los consumidores y usuarios en la fase previa de la contratación: la tutela de la libertad negocial", en Derecho (privado) de los consumidores, L. Miranda y J. Pagador (coords.), Madrid, Marcial Pons, 20 i 2, 87 ss. 
Empero, la información contenida en la publicidad debe ser fiel a la realidad y cumplir con los requisitos exigidos en la Ley I 480 de 20 I I, y no debe perderse de vista que, aunque como frente a este tipo de bienes el consumidor suele no conformarse con la información dada en la publicidad, sino que normalmente se dirige hacia el constructor o promotor inmobiliario a aumentar esta información, lo que se diga en la publicidad debe concordar con lo que luego se encuentra el consumidor en un folleto más detallado o en la sala de ventas de la constructora, ya que si la primera se refiere a aspectos objetivos no es meramente sugestiva, y en caso de inducción a error o engaño se configura publicidad engañosa. Esta aclaración, que pudiera parecer innecesaria o redundante, se hace porque en la práctica contractual se alega que un consumidor no podría ser engañado si luego se le aclara la información antes de que se obligue, lo cual no es de recibo, porque la discordancia entre las dos informaciones configura el engaño o la inducción a error. Cosa bien distinta será que el medio de difusión de la publicidad con que tiene contacto el consumidor originalmente no permita incluir toda la información, caso en el cual, sin que sea inducido a engaño o error, esta podrá ser complementada por otros medios antes de que el consumidor se obligue.

A continuación, para ilustrar el tema, se examinarán algunos casos de sanciones impuestas por la sic en la materia, para efectos de corroborar qué tipo de información se ha entendido que configura publicidad engañosa y destacar algunos aspectos que se consideran interesantes:

- La Corte Suprema de Justicia se pronunció en una sentencia de 20 I I $^{[24]}$, en una acción de grupo iniciada por unos copropietarios, en la que se exigía la responsabilidad por publicidad engañosa respecto de un proyecto inmobiliario. En este caso llama la atención que la sic sancionó la publicidad engañosa por vía administrativa, y a pesar de que parte de la argumentación de los demandantes se centró en dicha sanción, un error de índole probatoria, al no aportarse una copia idónea de dicho acto administrativo, impidió a los jueces, en las diferentes instancias y también en casación, valorar su fuerza probatoria para configurar la responsabilidad de la constructora. Es una lástima que esto haya ocurrido, porque está pendiente de verificación la validez probatoria y el efecto jurídico de la sanción administrativa por publicidad engañosa que emite la SIC en un proceso de responsabilidad por publicidad engañosa ante un juez ordinario. Llama la atención igualmente que en algunos casos, como pudo ocurrir en este, la publicidad al parecer dice una cosa y los contratos o precontratos, incluida el acta de entrega del inmueble, aceptada y firmada por el consumidor, dicen otra; el consumidor no se fija y da su consentimiento a pesar de que hay discrepancias en la información. En la sentencia en mención, los fundamentos del tribunal desvirtúan las afirmaciones de la parte demandante, considerando el despacho que

24 Corte Suprema de Justicia, Sala de Casación Civil, I de noviembre de 20 I I, exp. I IOO I-3 IO3or 8-2002-00292-oi, M.P.: Ruth Marina Díaz Rueda. 
la aceptación por parte del consumidor puede sanear el engaño. Sin embargo, cabe preguntarse si es reprochable la conducta de un constructor que anuncia en la publicidad unas condiciones objetivas del inmueble y luego en la promesa de contrato o en el contrato mismo modifica dichas condiciones sin advertir al consumidor, esperando que el consumidor lea completamente unos documentos que casi nadie lee en su totalidad. ¿Acaso esta conducta no es contraria a la buena fe? A todas luces es desleal, pues el consumidor actúa basado en la buena fe y la confianza legítima que le generan las relaciones precontractuales que ha establecido con el productor, confianza que no puede ser quebrantada.

- En Resolución n. ${ }^{\circ}$ I 3385 del 30 de abril de 2008, la sic reiteró la sanción a una empresa inmobiliaria por incurrir en publicidad engañosa al ofrecer a los consumidores unos apartamentos sin identificar plenamente el área privada, el área construida y el área total. $\mathrm{Al}$ respecto dijo la entidad: "la inmobiliaria tiene la carga de la buena fe y transparencia dentro de lo que ofrece al público y la información suministrada debe ser suficiente y veraz, de tal forma que las dudas que surjan en los futuros compradores sean mínimas y no el resultado de la falencia en la que incurrió la inmobiliaria al brindar una información no sólo incompleta sino que falta tajantemente a la verdad, como es la de ofrecer un área correspondiente a una unidad de vivienda, a determinado precio, para posteriormente concretar el negocio con base en la misma suma, pero sobre un área inferior a la ofrecida, resultante de sustraer de la inicial la correspondiente a bienes comunes de uso exclusivo".

- Mediante Resolución n. ${ }^{\circ} 43404$ del 30 de octubre de ese mismo año, la sIC se pronunció en una investigación administrativa iniciada por una queja de un consumidor que denunció que se había promocionado que un conjunto residencial iba a tener cerramiento y una cancha de microfútbol, y sin embargo no se cumplió con ninguna de estas dos cosas. La constructora alegó que el cerramiento era una "mera liberalidad" que iba a asumir el constructor, pero los vecinos no permitieron hacerlo; y en cuanto a la cancha de microfútbol adujo que no se pudo construir porque el Distrito Capital no otorgó la licencia. La sic, frente a esta defensa, señaló: "El argumento expuesto por la investigada, según el cual hubo un error en la publicidad al anunciar un cerramiento del conjunto, no es de recibo para el Despacho, pues dicha información tiene la entidad suficiente para influir en la decisión del consumidor, el cual no está en la obligación de asumir las consecuencias de una conducta descuidada por parte de la constructora al hacer ofrecimientos que no son factibles de ser cumplidos, pues como se indicó, un cerramiento requiere de una licencia especial que nunca fue solicitada, y en consecuencia, por más atractiva que quiera hacerse ver una campaña, ella no puede contener información que no se ajuste a la realidad, pues dicha conducta es constitutiva de publicidad engañosa". En este caso debe resaltarse que se trata de publicidad engañosa que consolida además un incumplimiento del contrato, no frente a la unidad de vivienda misma, sino frente a las características del conjunto 
residencial ofrecido, aspecto que también es importante para el consumidor en la toma de la decisión de compra, por lo que se puede afirmar que el constructor vende no solamente una vivienda, sino que al promocionar un conjunto residencial con ciertas características también la información sobre las áreas comunes y en general sobre la copropiedad hace parte de la oferta y se integra al contrato de compraventa. Cabe agregar que ese incumplimiento contractual da lugar a otro tipo de acciones de tipo jurisdiccional, ya que en este caso la sic actuó en calidad de autoridad administrativa.

- En otro caso, la sic sancionó a una inmobiliaria por incluir en la publicidad de un proyecto inmobiliario la expresión "Amplias zonas verdes", cuando en realidad dicho conjunto habitacional no contaba con tales zonas verdes y estas correspondían a un parque público que se debería construir en futuro por la Alcaldía de Bogotá en una zona aledaña al conjunto (Res. n. ${ }^{\circ} 9$ I 49 del 20 de febrero de 20I4). La empresa fue multada y en este caso no ordenó la publicidad correctiva pues la difusión de la publicidad ya había cesado. Este caso hace pensar que los constructores también suelen hacer afirmaciones sobre las características del sector en que se ubica el inmueble, por ejemplo en cuanto a vías de acceso, y es claro que también deben corresponder a la realidad.

- En un caso, también sancionado en 20I4, un consumidor denunció que un proyecto inmobiliario denominado "La Felicidad Ciudad Parque", no tenía parques para recreación de los niños, a pesar de haberse anunciado así. La sic en su investigación encontró que dicho proyecto sí contaba con los parques publicitados, según constaba en el plan parcial de ordenamiento territorial, pero la fecha de esa construcción era incierta y se entregaron varias etapas del proyecto sin la construcción efectiva de dichos parques. No obstante, la entidad consideró insuficiente la información contenida en la publicidad, señalando: "No basta con informar que los parques se construirán, también resulta necesario informar sobre la oportunidad y las condiciones que se deben agotar para su construcción, en la medida en que la decisión de consumo de los potenciales habitantes del proyecto urbano puede basarse en el disfrute real y efectivo de los parques y el equipamiento público ofrecido por el anunciante" (Res. n. ${ }^{\circ}$ 6r 242 del ro de octubre de 20I4). Por lo tanto la entidad consideró que la publicidad inducía a error a los consumidores al no ser clara, oportuna, eficiente y además veraz. Llama la atención que la sic en este caso dice que sanciona la publicidad "sin que se configuren los elementos propios de la publicidad engañosa", y esto es un error conceptual grave que afectó parcialmente la decisión, pues la misma Ley I480 de 20 I i dice que la publicidad que induzca o pueda inducir a error es engañosa, es decir, que el hecho de que sea potencialmente engañosa configura ya la infracción, y el hecho de que el consumidor se quejara implicaba que ya había consumidores que se sentían frustrados con la compra. Sin embargo, ese fue el argumento que utilizó la entidad para no multar a la empresa constructora. En este caso ordenó la publicidad correctiva, pero no la multa por vía administrativa, lo cual obedeció 
tal vez a que la entidad no consideró que se hubiera configurado la publicidad engañosa. No obstante, se reitera que no se comparte la lectura de la Ley I480 de 20 I que hizo la entidad pues la publicidad era efectivamente engañosa.

- Otro caso de sanción por publicidad engañosa se dio mediante Resolución n. ${ }^{\circ}$ I 5420 del 25 de marzo de 20 i . En este caso la Secretaría del Hábitat de Bogotá remitió para investigación a la sic una presunta violación a las normas de protección al consumidor por publicidad engañosa. Se trataba de una falta de concordancia entre la foto exhibida en la publicidad y el proyecto inmobiliario entregado con respecto a los colores de los muros. La constructora alegó desconocer quién había hecho esa publicidad, pues a pesar de que se trataba del mismo proyecto inmobiliario, negaba su autoría. Ante este argumento la sIC aplicó la carga dinámica de la prueba, asumiendo que corresponde a la investigada aportar las pruebas de sus afirmaciones: "Llama la atención del Despacho que la investigada no aportó a la actuación ninguna de sus publicaciones, folletos donde consten sus argumentos de defensa" (Res. n. ${ }^{\circ}$ I 5240 de $201 \mathrm{I}$ ). Concluye la entidad que la investigada no aportó prueba alguna de la adulteración o falsificación de su publicidad, carga que le correspondía conforme al artículo 32 del entonces vigente Decreto 3466 de 1982 (anterior Estatuto de Protección al Consumidor). Del análisis de la pieza publicitaria en cotejo con las fotografías del estado final del conjunto residencial aportadas por la quejosa, la sic concluyó falta de concordancia entre las fotografías de la publicidad y la realidad en cuanto al cerramiento del conjunto ofrecido en la publicidad, la arborización incluida en la publicidad y las características de la fachada. La sic concluyó que la pieza publicitaria induce a error a los consumidores y se torna insuficiente la información dada en la misma, por lo que es engañosa, e impuso una sanción pecuniaria a la empresa.

Estos cuatro últimos casos referenciados tienen como característica en común que se trata de publicidad engañosa por indebida información referente a las características del proyecto inmobiliario, frente a zonas comunes o características de la copropiedad, lo cual da un indicio de que se trata de una infracción frecuente en materia de relaciones de consumo inmobiliarias.

Nótese que por tratarse de actuaciones por vía administrativa, la sic no ordena efectuar cambios a dichas construcciones, pues estas órdenes corresponderían a acciones iniciadas por vía jurisdiccional; solamente impone multas por vía administrativa y publicidad correctiva cuando a ella hay lugar, es decir, cuando la publicidad aún se está emitiendo en el mercado. Este aspecto es relevante para cuando se estudien adelante las funciones que tienen las alcaldías municipales en la materia. Aunque no olvidemos que la sic por vía jurisdiccional y los jueces ordinarios pueden conocer de asuntos derivados de publicidad engañosa para atacar la validez del contrato y la responsabilidad civil precontractual o contractual derivada de publicidad engañosa, tal y como lo indicó la Corte Suprema de Justicia en la citada sentencia de noviembre de 20 I. 
En cuanto al tipo de acciones con que cuenta el consumidor por información o publicidad engañosa, este podrá acudir ante la sic para denunciar la publicidad por vía administrativa con miras a que se protejan los intereses generales de los consumidores. Cuando el consumidor tenga una pretensión personal derivada de la publicidad o información engañosa puede acudir por vía jurisdiccional ante la sic para demandar pidiendo los perjuicios derivados de la publicidad engañosa, posibilidad que existe también ante el juez ordinario, ante el cual inclusive puede demandar la nulidad del contrato por dolo como vicio del consentimiento.

\section{La protección contractual al consumidor inmobiliario}

Una vez el vendedor (constructor o promotor inmobiliario) y el comprador (consumidor inmobiliario) han celebrado el contrato de compraventa de la unidad habitacional, entramos claramente en la etapa contractual, regida en primera medida por el contrato y las normas de los contratos, y específicamente de la compraventa de derecho común. Pero no debe perderse de vista que, al existir además una relación de consumo, se está frente a una compraventa de inmueble en la que tienen vocación para aplicarse las normas de protección al consumidor. Allí, las obligaciones principales del contrato se tornan lógicamente cardinales, el comprador tiene que pagar el precio, y el vendedor tiene que hacer la tradición del inmueble, lo que comprende su entrega física y posterior registro. Además las obligaciones derivadas de la naturaleza del contrato, comprendidas generalmente en la escritura pública, devienen importantes, tales como el saneamiento por evicción, el saneamiento por vicios ocultos, entre otros. No obstante, más allá de esas obligaciones derivadas del derecho común, y comoquiera que para el ámbito de este artículo interesa revisar los aspectos regulados por las normas de protección al consumidor, se abordará la obligación de garantía por calidad, idoneidad y seguridad de los inmuebles (A), las cláusulas abusivas (B) y luego la responsabilidad por producto defectuoso $(\mathrm{C})$.

\section{A. Garantía por calidad, idoneidad y seguridad de bienes inmuebles}

Conforme al artículo 5, numeral 5, de la Ley i480 de 20 I I, la garantía es una "obligación temporal, solidaria a cargo del productor y el proveedor, de responder por el buen estado del producto y la conformidad del mismo con las condiciones de idoneidad, calidad y seguridad legalmente exigibles o las ofrecidas". Por lo tanto, la obligación de garantía es una obligación definida en el tiempo, y la misma Ley I480 de 20 I i prescribe que la garantía legal para bienes inmuebles por estabilidad de la obra es de diez años, y el término de garantía para los acabados y líneas vitales, según la misma norma, de un año.

Adicionalmente debe recordarse que existen normas del derecho civil o comercial que pueden resultar aplicables en casos de fallas o deterioros del in- 
mueble imputables al vendedor; conviene hacer alusión a ellas. Desde el punto de vista del derecho civil existe a cargo del constructor, al tenor del artículo 2060 c. c., numeral 3, una obligación de responder durante diez años, en caso de que el edificio perezca o amenace ruina, por los vicios de construcción, por los vicios del suelo y los vicios de los materiales. Esta obligación decenal está a cargo del constructor (empresario, según el código civil) y a favor del dueño de la obra. A este tema le apareció un nuevo ingrediente con la Ley I 796 de julio de 20I6, denominada "Ley de Vivienda Segura", por la cual se establecen medidas enfocadas a la protección del comprador de vivienda, entre otros temas, y que con respecto a lo dispuesto en las dos normas citadas estableció que, "en el evento que dentro de los diez (Io) años siguientes a la expedición de la Certificación Técnica de Ocupación de una vivienda nueva, se presente alguna de las situaciones contempladas en el numeral 3 del artículo 206o del Código Civil, el constructor o el enajenador de vivienda nueva, estará obligado a cubrir los perjuicios patrimoniales causados a los propietarios que se vean afectados" (art. 8). Igualmente, el parágrafo de este artículo dice: "El constructor o el enajenador de vivienda nueva deberán amparar los perjuicios patrimoniales a los que hace referencia la presente ley a través de su patrimonio, garantías bancarias, productos financieros o seguros, entre otros". En consecuencia, surge el mandato de asegurar o garantizar los perjuicios patrimoniales por eventuales daños sufridos por el inmueble en caso de que perezca o amenace ruina, la cual entra a complementar la obligación decenal del artículo 2060 c. c. y busca de una manera loable constituir una garantía para el pago de los eventuales perjuicios que se ocasionen al propietario. No es claro en esta norma qué tipo de garantía se debe constituir, por qué montos, a partir de cuándo y hasta qué momento tendrá vigencia la misma; seguramente se trata de aspectos que la reglamentación aclarará. Por el contrario, esta norma no se confunde con las normas de protección al consumidor, en primer lugar porque tiene finalidades diferentes a la garantía de calidad, idoneidad y seguridad, ya que la norma del artículo 2060 c. c. busca garantizar el pago de perjuicios y la garantía del derecho del consumo tiene finalidades de cumplimiento 25 . Se concluye más bien que las normas se complementan.

Ahora bien, es una norma que seguramente aprovecharán los consumidores, a pesar de no hacer parte del exclusivo grupo de normas encaminadas a protegerlos, ya que en el caso de proyectos inmobiliarios en que se venden las unidades a unos nuevos propietarios en una propiedad horizontal, se entende-

25 J. Tamayo Jaramillo y J. Ossa Gómez ("La responsabilidad civil y los seguros en la construcción de inmuebles: una aproximación comparativa entre el derecho civil colombiano y francés", Revista Ibero-Latinoamericana de Seguros, 43(24), julio-diciembre de 20 I 5, I76) apoyan esta afirmación: "La primera, denominada garantía legal, aplicable únicamente por vicios de calidad, idoneidad o seguridad, podría dar derecho al consumidor (piénsese en el adquirente del inmueble, o quien lo habite para sus necesidades no empresariales) únicamente a que se repare el bien o se devuelva el dinero si el vicio se repite, dentro del corto plazo de caducidad de la acción". 
rá que los beneficiarios de dicho seguro o garantías, que complementarán las obligaciones surgidas del artículo 2060 c. c., son los compradores-consumidores (subadquirentes) y la copropiedad misma frente a las zonas comunes, dado que la Corte Suprema de Justicia ha admitido que los subadquirentes son titulares de la acción derivada del artículo 2060 c. c. ${ }^{26}$.

De otro lado, la norma del artículo 2060 tampoco impacta la responsabilidad por productos defectuosos contemplada en la Ley I480 de 20 I I, porque no ampara los daños corporales ocasionados a las personas por la ruina del inmueble o los daños ocasionados a bienes diferentes al inmueble, especies de daño en los que se centró el Estatuto de Protección al Consumidor.

Encontramos un segundo escenario, aún dentro del derecho común, entre el comprador y el vendedor del inmueble, pues en caso de que se presenten vicios ocultos existe la obligación de saneamiento a cargo del vendedor, conforme a las reglas que rigen la compraventa en el código civil (arts. I9I4 ss. c. c. y 934 c. de co.). Estas obligaciones no se pueden confundir con la garantía del Estatuto del Consumidor, pues las diferencias son marcadas ${ }^{27}$.

Retomando el tema de la garantía por calidad, idoneidad y seguridad, que es de interés central en este artículo, la misma surge a cargo del productor o proveedor frente al consumidor, ya que es necesaria la configuración de una relación de consumo. Se debe mirar entonces la finalidad de la adquisición del inmueble para determinar si el comprador o la persona que usa o disfruta el inmueble es consumidor, ya que esta acción puede ser ejercida también por una persona diferente al vendedor, quien usa o disfruta el bien.

La obligación de garantía es solidaria entre los intervinientes en la construcción y comercialización del proyecto inmobiliario o el inmueble nuevo, que conforme a las definiciones legales puedan ser considerados como productor o proveedor. Esta obligación comprende que el bien sea conforme, es decir, que el inmueble nuevo que se venda en Colombia cumpla con la calidad, idoneidad y seguridad del bien legalmente exigibles o las ofrecidas (art. 5 num. 5 Ley I 480 de 200I). Por calidad se entiende, según esta norma: "Condición en que un producto cumple con las características inherentes y las atribuidas por la información que se suministre sobre él”; ello implica que el inmueble tenga las características que tienen todos los inmuebles nuevos de su tipo o las que el vendedor le in-

26 Corte Suprema de Justicia, Sala de Casación Civil, 5 de junio de 2009, exp. C-0800 3 I 03006 I 993 08770-or, M.P.: Jaime Arrubla Paucar. En sentencia de 7 de octubre de 2016 la Corte reiteró esta posición: Corte Suprema de Justicia, Sala de Casación Civil, 7 de octubre de 20r6, SCi4426-2016, rad. 4100131030042007000790 I, M.P.: Ariel Salazar Ramírez.

$27 \mathrm{Al}$ respecto ver J. C. Villalba Cú́lLaR, "La responsabilidad del productor por garantías de bienes y servicios en el derecho colombiano", Revista Prolegómenos Derechos y Valores, enero-junio de 20I3, 45-67; D. Ossa Gómez, "La responsabilidad civil en el Estatuto del Consumidor. Las garantías de calidad, idoneidad, y seguridad de los productos", Revista Estudios de Derecho, Lxx, $2013,156,237-264$. 
formó al consumidor. En cuanto a lo inherente, debe tenerse en cuenta que las normas obligatorias de construcción (nacionales o municipales) y de propiedad horizontal imponen requisitos mínimos en cuanto a las especificaciones de los inmuebles nuevos, las cuales deben ser cumplidas por los constructores; todos esos requisitos se entienden como inherentes y por lo tanto la falta de alguno de ellos implicará una infracción a la obligación de garantía, sancionable desde la órbita de las normas de protección al consumidor. Igualmente lo inherente se referirá a todo aquello que de manera habitual en el mercado cumple o hace parte de un inmueble, por ejemplo, que tenga una zonas comunes destinadas a la recreación de los niños, o inclusive sería lógico pensar que si el inmueble es nuevo, los accesorios y bienes que son considerados inmuebles por adhesión o destinación sean igualmente nuevos. Para soportar dichas afirmaciones basta recordar que el artículo 3 de la Ley I 48 o de 20 i I, en su numeral I.I, postula que los consumidores tienen derecho a recibir productos de calidad de conformidad con la garantía legal, lo ofrecido y las condiciones habituales del mercado.

Mientras tanto, por idoneidad, según el Estatuto de Protección al Consumidor, se entiende la "[a]ptitud del producto para satisfacer la necesidad o necesidades para las cuales ha sido producido o comercializado", lo que implica que un inmueble nuevo destinado a vivienda será idóneo si efectivamente puede ser habitado en las condiciones normales que se esperan o que se promocionaron (art. 5 num. 6). Igualmente dice la norma que cuando exista reglamento técnico el bien inmueble debe cumplir con el mismo (art. 6). Al respecto debe acotarse que en Colombia existen reglamentos técnicos aplicables a bienes inmuebles nuevos, por ejemplo, el reglamento técnico para redes internas de comunicaciones (RITEL), expedido por la Comisión de Regulación de Comunicaciones (CRC) mediante Resolución n. ${ }^{\circ} 4662$ de 2013 , así como los reglamentos técnicos atientes a instalaciones eléctricas, instalaciones de gas y barras corrugadas. El reglamento vigente de sismorresistencia NSR-IO quedaría allí cobijado, y este compromete, además de la calidad, la seguridad del inmueble. El no cumplimiento de lo especificado por el reglamento técnico implica una infracción a la obligación de garantía, y en este caso el producto se presumirá inseguro según el numeral i4 del artículo 5 del mencionado Estatuto.

Así mismo, en el caso de no entrega del inmueble o retardo en ella, este asunto queda cobijado por la obligación de garantía, dado que la imposibilidad de gozar del bien según la norma hace parte de dicha obligación (art. I I num. 6). El no cumplimiento de la entrega de las áreas privadas o comunes anunciadas también queda comprendido en este tema, tanto como el incumplimiento en materia de acabados y líneas vitales del inmueble, así se trate de asuntos meramente estéticos, ya que estos se ligan a la calidad del bien. Con mayor razón el deterioro de los acabados y de la estructura del inmueble, ya sea al interior de las unidades habitacionales o en áreas comunes, se entiende incluido en la calidad. Adicionalmente, la obligación de garantía también cobija la seguridad del bien, 
es decir, el caso en que un bien inmueble nuevo, por un problema de construcción o diseño, no ofrezca la razonable seguridad a que los consumidores tienen derecho. En este último caso el consumidor, sin necesidad de haber sufrido un daño, puede exigir que se ordene al constructor adecuar el inmueble para garantizar dicha seguridad o, en caso de que no sea posible, pedir la indemnización de los perjuicios.

A lo anterior se suma que el vendedor es solidariamente responsable, junto con el fabricante, por la garantía de los bienes inmuebles por adhesión que hacen parte del inmueble, en zonas comunes o privadas, por ejemplo, los ascensores, las estufas, los calentadores, etc. En la práctica el vendedor del inmueble suele ceder al comprador (consumidor) las garantías sobre esos bienes en el acta de entrega del inmueble, pero esta estipulación puede ser considerada no escrita, ya que la Ley I480 de 20 I I en su artículo 43 considera abusivas las cláusulas que "restrinjan o eliminen la facultad al usuario del bien para hacer efectivas directamente ante el productor y/o proveedor las garantías a que hace referencia la presente ley", y por tratarse de bienes inmuebles por adhesión el vendedor no podría eximirse completamente de esa obligación de garantía trasladándola a un tercero.

Es pertinente examinar ahora qué es lo que puede exigir el consumidor como consecuencia de la garantía del inmueble, es decir a qué queda obligado el constructor. La normatividad de protección al consumidor en materia de garantía permite al consumidor pedir en primer lugar que se repare el bien, si la reparación es posible, y en caso de que se hubiese reparado y la reparación falle o que la reparación no sea posible, procede que el consumidor escoja entre pedir la devolución del dinero o la sustitución del bien por uno de igual calidad o de similares características. El Decreto 735 de 20 I 3, reglamentario de este tema, hizo algunas precisiones sobre el procedimiento a seguir para cumplir esa obligación en la etapa de reclamación ante el productor o proveedor. Precisó dicha norma que para el caso de reclamaciones por acabados o líneas vitales, una vez presentada la reclamación por el consumidor, el productor o proveedor, dentro de los cinco días hábiles siguientes, realizará una visita de verificación al inmueble y deberá responder por escrito al consumidor dentro de los diez días hábiles siguientes. Una vez cumplido esto, en caso de proceder la reparación, el productor o proveedor cuenta con un término de treinta días hábiles para efectuarla; y al tenor de la misma norma, si se repite la falla, "el consumidor a su elección, podrá solicitar una nueva reparación, la reposición del acabado o la línea vital afectados o la entrega de una suma equivalente al valor del acabado o línea vital afectados” (art. I3). En caso de reclamación por estabilidad de estructura el procedimiento es el mismo pero los términos son más amplios, treinta días prorrogables hasta por otros treinta para responderle al consumidor luego de efectuada la visita, $y$ el plazo para efectuar las reparaciones dependerá de lo que digan los estudios técnicos con respecto a la solución a implementar. Cuando no proceda la reparación por estabilidad de la obra el productor o proveedor deberá devolverle el 
dinero al consumidor debidamente indexado; y si existiese crédito hipotecario tomado por el consumidor, deberá reintegrar al consumidor el valor de la cuota inicial así como las cuotas pagadas a la entidad financiera y cancelar con la entidad financiera el saldo total del crédito (art. I 3 par. segundo).

Vale la pena resaltar que en uno de los casos de los edificios contiguos al edificio Space, la Delegatura para Asuntos Jurisdiccionales de la sic en primera instancia (sentencia del 2 I de enero de 2016) ordenó la devolución del dinero a los compradores de los inmuebles y en segunda instancia, mediante sentencia del 7 de septiembre de 2016 (audiencia de fallo), la sala de decisión del Tribunal Superior de Bogotá ${ }^{28}$ confirmó la sentencia de primera instancia en que se ordena a las demandadas reintegrar debidamente indexado el dinero pagado por la compra de los inmuebles. En este caso las demandadas alegaron cumplir con la obligación de garantía con el reforzamiento de los inmuebles, petición que no fue aceptada por el Tribunal con base en los peritajes y pruebas obrantes en el proceso, motivo por el cual la reparación del inmueble no era viable y se condenó a la devolución del dinero. En esta sentencia se ordenó la indemnización de los perjuicios por información engañosa, pretensión denegada por la sIc, ya que el Tribunal consideró que el hecho de haber manifestado en las promesas de compraventa que los inmuebles cumplían con las normas técnicas obligatorias configuró un engaño que ameritaba la reparación de los daños causados ${ }^{29}$.

En cuanto a la legitimación para exigir la garantía, está legitimado por activa el consumidor, es decir, la persona que adquirió como comprador la vivienda nueva, y en los términos de la Ley I480 de 20 I I también estará legitimada la persona que use o disfrute el bien, sea el arrendatario, o en general cualquier clase de tenedor o poseedor legítimo del bien. Además, el Decreto 735 de 2013 legitima por activa al administrador de la propiedad horizontal para las demandas o quejas relativas a la calidad e idoneidad de bienes comunes.

En lo que respecta a la competencia sobre el conocimiento de quejas o demandas por garantía de calidad e idoneidad, se deben hacer algunas precisiones. Según el Estatuto y las normas que rigen la competencia en asuntos de protección al consumidor, la sic conocerá de las demandas que por vía jurisdiccional interponga el consumidor, por ejemplo, para reclamar la efectividad de la garantía porque existen deficiencias en el inmueble que el constructor no quiere corregir y se pretende que sean corregidas. En este tipo de acciones no se puede acumular la pretensión de indemnización de perjuicios conforme a lo establecido en el Decreto 735 de 2013 en su artículo 22.

28 Tribunal Superior de Bogotá, rad. 20I4-I62-47-02, acción de protección al consumidor de Andrea Henao y otros contra Alsacia Constructora S.A., Lérida Constructora S.A., Gonelas S.A.S. en liquidación y Calamar cDo s.A.s.

29 Ibíd. 
La sic, en concepto n. ${ }^{\circ} 2043842$ de 2002 , aclaró la competencia en materia administrativa por garantía de bienes inmuebles entre la sic y las alcaldías de la siguiente forma:

Al tenor de los artículos 42 y 43, literal f), en concordancia con el numeral 4 del artículo 2 del decreto 2 I 53 de 1992, por regla general corresponde a la Superintendencia de Industria y Comercio, imponer las sanciones administrativas a que haya lugar por el incumplimiento de las condiciones de calidad e idoneidad de todos los bienes y servicios, salvo que, como ya se dijo, dicha competencia le haya sido otorgada a otra autoridad.

Ahora bien, conforme a los artículos i y 2, especialmente los numerales 6, 7 y 9, en concordancia con la ley 66 de 1988 y el decreto 26 Io de 1979, corresponde a la Alcaldía Mayor de Bogotá, D.C., a través de la Subsecretaria de Control de Vivienda y las alcaldías municipales en las demás regiones del país, velar porque los inmuebles adquiridos en virtud de relaciones de consumo cumplan con las condiciones de calidad e idoneidad mínimas que deben cumplir en orden a satisfacer las necesidades para las cuales fueron adquiridos, de tal manera que, en este caso por haberle sido asignada dicha competencia administrativa a otras autoridades, ésta no es ejercida por la Superintendencia de Industria y Comercio.

En tal sentido, corresponde a la Subsecretaría de Control de Vivienda y a las alcaldías, imponer las sanciones administrativas a que haya lugar por el incumplimiento de las condiciones de calidad e idoneidad de inmuebles adquiridos a través de una relación de consumo.

De manera que la sic no es competente para iniciar investigaciones e imponer sanciones administrativas relativas a la calidad e idoneidad de los inmuebles, aunque guarda competencia respecto de todos los otros asuntos de protección al consumidor por vía administrativa, como publicidad engañosa, omisión al deber de información, abusos contractuales, entre otros. Solamente será competente para ordenar el cumplimiento de la garantía de bienes inmuebles por vía jurisdiccional, competencia que comparte con los jueces civiles, para lo cual se debe tener en cuenta además que la Superintendencia no cuenta con la facultad de ordenar indemnizaciones de perjuicios derivadas de la garantía.

\section{- La reclamación por vía administrativa ante la Secretaría del Hábitat en Bogotá D. C. o en las alcaldías municipales}

Tal y como se viene de afirmar, la sic no conoce por vía administrativa de asuntos relacionados con la calidad e idoneidad de los inmuebles, pues esta función legalmente la tienen las alcaldías municipales. 
Lo que resulta llamativo, examinando algunos casos de protección administrativa ejercida por la Secretaría del Hábitat de Bogotá, es que esta entidad puede imponer multas y además ordenar hacer reparaciones y arreglos a favor del consumidor, por lo que podría, sopesando cada caso, ser una vía más expedita que acudir ante la sic.

No obstante, a partir de un estudio presentado recientemente se pudo determinar que las multas impuestas por la Secretaría del Hábitat en algunos casos son poco disuasivas, debido a los montos de las mismas, que oscilan en promedio entre los dos millones y los cincuenta millones de pesos. En efecto, las reparaciones que ordena la Secretaría del Hábitat en Bogotá por menores cuantías son frecuentemente efectuadas por los constructores; pero, por el contrario, cuando se trata de reparaciones mayores y sobre todo en áreas comunes, el incumplimiento a la orden de la Secretaría del Hábitat es frecuente, lo que permite concluir que algunos constructores prefieren pagar la multa que efectuar la reparación $3^{30}$. Resulta llamativo ver entonces que la Secretaría del Hábitat puede ser más eficiente para resolver asuntos en los que por vía jurisdiccional la sIC conserva competencia en la materia, ya que frente a reparaciones solicitadas por el consumidor por daños menores y acabados, además de imponer la multa, esta entidad ordena efectuar dichas reparaciones y por regla general el constructor cumple. Mientras que si el consumidor pretende esto mismo ante la sic por vía jurisdiccional tiene que soportar el trámite de una demanda, larga y cargada de formalidades, para que en un término no menor a un año se ordene la reparación debida.

Revisando las decisiones de la Secretaría del Hábitat ${ }^{3}$, las cuales jurídicamente, por regla general, están bien estructuradas, se evidencia que es el propietario o su representante el legitimado para interponer la queja, mientras que conforme a las normas de protección al consumidor esta legitimación es más amplia, pues se extiende a quienes usan o disfrutan el bien. Igualmente, frente a deficiencias en las áreas comunes inicia investigación administrativa con base en la queja formulada por un copropietario, sin necesidad de que la presente el representante legal de la copropiedad ${ }^{32}$. En algunos casos, cuando esta entidad evidencia infracciones de normas de protección al consumidor, como publicidad o información engañosa, remite a la sic para su conocimiento.

Se evidencia así que la Secretaría del Hábitat, cuya función no es directamente de protección al consumidor, termina ejerciendo esta función de manera

30 Universidad Sergio Arboleda, Superintendencia de Industria y Comercio y Red Nacional de Protección al Consumidor, Documento técnico (cartilla): Análisis de las problemáticas de los consumidores del sector de la construcción, Bogotá, 2016, 70.

3 I Para la redacción de este artículo se revisó una muestra de resoluciones de esta entidad que aparecen enlistadas al final del artículo.

32 P. ej., Res. n. ${ }^{\circ} 2$ I 83 de 2012 y Res. n. ${ }^{\circ} 879$ de 2013. 
indirecta a través de la aplicación del mandato legal. Nótese además que la Secretaría del Hábitat no fundamenta sus investigaciones y decisiones con base en las normas de protección al consumidor, sino en las normas que rigen la actividad de la construcción a nivel nacional y local, tales como la Ley 66 de i968, el Decreto Ley 26ro de I979, el Decreto Ley o78 de I987, el Decreto 4I9 de 2008, el Acuerdo 079 de 2003 (Código de Policía de Bogotá) y el Acuerdo 20 de I $995^{[33]}$. Esas normas desarrollan una terminología diferente a la norma de protección al consumidor y, por ejemplo, para el caso de deficiencias constructivas hablan de afectaciones gravísimas, graves y leves; y en algunos casos, como el Decreto 4I 9 de 2009, contienen términos diferentes a los de la Ley I480 de 20 I I en materia de garantía, para interponer las quejas por estas afectaciones, ya que, por ejemplo, para el caso de afectaciones graves se cuenta con un término de tres años. Igualmente, sus procedimientos son netamente de carácter administrativo y se rigen por las normas del código de procedimiento administrativo y de lo contencioso administrativo (CPACA).

Esta función que está ejerciendo la Secretaría del Hábitat en Bogotá se desarrolla paralelamente por las alcaldías en todos los municipios del país, por lo que en cada caso deberá tenerse en cuenta el obrar de dichas autoridades en materia de protección al consumidor inmobiliario.

\section{B. Cláusulas abusivas}

En el derecho del consumo la protección al contratante vulnerable -consumidor- nace como parte de la necesidad de evitar o controlar los riesgos propios de la contratación en masa, que por excelencia utiliza la figura del contrato de adhesión ${ }^{34}$.

El consumidor inmobiliario es por excelencia un adherente en las relaciones pre-contractuales y contractuales en que participa. Este rol pasivo en la contratación implica riesgos para el consumidor, riesgo contractual que se centra en el peligro de abuso en el contenido del clausulado que le es impuesto por parte del vendedor. Esta situación no es ficticia, y en la práctica se presentan con frecuencias las denominadas "cláusulas abusivas" en los contratos inmobiliarios con consumidores. Según la Ley I480 de 20 I I son cláusulas abusivas "aquellas que producen un desequilibrio injustificado en perjuicio del consumidor y las que, en las mismas condiciones, afecten el tiempo, modo o lugar en que el consumidor puede ejercer sus derechos" (art. 42). Aunado a lo anterior, en el artículo 43 se establece una lista negra de cláusulas abusivas, y en caso de que en un contrato celebrado con un consumidor aparezca alguna cláusula que corresponda a esta

33 En todas las resoluciones revisadas aparece citada toda o parte de esta normatividad.

34 Gual Acosta, J. M. "El control sobre cláusulas abusivas un régimen en evolución”, Revista IUSTA, n. ${ }^{\circ}$ 30, enero-junio de 2009. 
tipología, se entenderá que la cláusula es abusiva de manera objetiva. En todo caso, una cláusula abusiva en contratos celebrados con los consumidores se tendrá por no escrita.

En un estudio realizado recientemente de una muestra de decisiones de la sic se estableció que para el ámbito nacional, en el periodo comprendido entre 2013 y 2015, las cláusulas abusivas más frecuentes a que se ven expuestos los consumidores inmobiliarios y que han sido objeto de sanción son las siguientes en orden de prelación ${ }^{35}$ :

- Las que vinculan al consumidor aun cuando el vendedor incumpla.

- Las que estipulan el pago de intereses no autorizados.

- Las que implican renuncia de los derechos del consumidor.

- Las que limitan la responsabilidad del productor.

- Las que implican el no reintegro de lo pagado por el consumidor.

- Las que trasladan la responsabilidad del productor.

- Las que presumen la voluntad del consumidor.

- Las que establecen la prohibición de resolver el contrato.

La doctrina española cita como cláusulas abusivas frecuentes en la contratación inmobiliaria con consumidores: a) la cláusula de reserva por parte del predisponente de la facultad de modificación unilateral del contrato; b) la cláusula reguladora del plazo de entrega de la vivienda; c) la cláusula de declaración de conformidad por el comprador de la entrega del inmueble; d) la cláusula de imposición del notario; e) las cláusulas que impongan al comprador asumir gastos que por naturaleza le corresponden al vendedor, la cláusula penal abusiva, las cláusulas de reducción de plazos de garantía y de ejercicio de derechos ${ }^{36}$. A su vez, González Carrasco señala algunas, de las cuales destacamos: a) las que limitan la responsabilidad del vendedor por incumplimiento; b) las cláusulas abusivas por falta de reciprocidad; c) las que imponen renuncias a los derechos del consumidor; c) las que imponen bienes accesorios o servicios no solicitados; d) las que imponen consecuencias desproporcionadas por el incumplimiento del contrato 37 . Por su parte, en el derecho argentino, Hernández y Esborraz nos ponen de presente como cláusulas abusivas frecuentes en el ámbito inmobiliario: a) la cláusula que coloca a cargo del adquirente el pago de los gastos y honorarios derivados de la preparación y otorgamiento de la titulación; b) la cláusula que impone al adquirente la prohibición genérica de ceder el contrato o los derechos emergentes del mismo sin la conformidad expresa del proveedor; c) la cláusula

35 Universidad Sergio Arboleda et al., ob. cit., 4I.

36 Cañizares Laso, A. (coord.), Cláusulas abusivas en la contratación inmobiliaria, Madrid, Tecnos, 2006, I08, I46, I6 I, I 80, 202, 266, 288.

37 González Carrasco, C. La contratación inmobiliaria con consumidores, Centro de Estudios de Consumo y Universidad Castilla-La Mancha, disponible en: https://www.uclm.es/centro/ces$\mathrm{co} / \mathrm{pdf} /$ comentarios/6.pdf 
que concede al proveedor el derecho de resolver el contrato luego de ejecutada una parte sustancial de la prestaciones, imponiendo al adquirente penalidades civiles exorbitantes; d) la cláusula que reserva al proveedor la interpretación del contrato o limita la hermenéutica al contenido del documento final por el cual se formalizó el negocio; e) la cláusula que concede al proveedor el derecho de modificar unilateralmente los términos del contrato o las prestaciones convenidas $3^{8}$. Observando este breve panorama comparativo, es claro que existen algunas coincidencias, por ejemplo la tendencia al control de los plazos y obligaciones a cargo del vendedor, el control exorbitante de la responsabilidad a través de cláusulas, la imposición de costos y trámites al consumidor que generalmente este no tiene a cargo.

Lo anterior indica que infortunadamente, en la contratación que se celebra con consumidores en materia inmobiliaria, las cláusulas abusivas no están ausentes, por el contrario, son relativamente frecuentes y han sido sancionadas por la sic en varias oportunidades, según lo demostró el estudio citado.

\section{Responsabilidad por bienes inmuebles defectuosos}

La responsabilidad por productos defectuosos es una subespecie de responsabilidad que busca la reparación de los perjuicios ocasionados a las personas con ocasión de la utilización de productos que presenten problemas en su fabricación, embalaje o diseño. La Ley I 480 de 20 I r reguló por primera vez el tema en Colombia, aunque existían antecedentes jurisprudenciales sobre el tema ${ }^{39}$. Lo contemplado en dicha norma permite incluir dentro de las hipótesis de responsabilidad por productos defectuosos los daños ocasionados por bienes inmuebles, es decir que un bien inmueble puede ser considerado un producto defectuoso en el derecho colombiano. Esto quiere decir que cuando un bien inmueble, por problemas en su fabricación o diseño, le cause daños (la muerte o lesiones corporales) a los consumidores, o a sus bienes, el constructor y todos los involucrados en la construcción y venta del inmueble deben responder por los daños causados. No obstante, Tamayo anota al respecto que la Ley I480 de 20 I I excluyó a los promotores inmobiliarios, "que en la práctica son los verdaderos

38 Hernández, C. A. y Esborraz, D. "Las cláusulas abusivas en la contratación inmobiliaria”, Colección de derecho privado, Abuso del derecho, Revista de la Facultad de Derecho y Ciencias Sociales de Rosario, 2006, 29, disponible en: http://www.saij.gob.ar/doctrina/dasfo6oo78-hernandezlas_clausulas_abusivas_en.htm

39 Corte Suprema de Justicia, Sala de Casación Civil, 30 de abril de 2009, exp. 25899-3193992-I999-00629-or, M.P.: Pedro Octavio Munar Cadena. Corte Suprema de Justicia, Sala de Casación Civil, 24 de septiembre de 2009, ref. 05360-31-03-001-2005-00060-0I, M.P.: César Julio Valencia Copete. 
responsables"40, afirmación respecto de la cual se considera que el promotor inmobiliario sí puede quedar cubierto dentro de la categoría de proveedor o expendedor según la definición del artículo 5 de dicha norma y, por ende, obligado a responder. En efecto, en el artículo 20 del Estatuto del Consumidor se dice: "El productor y el expendedor serán solidariamente responsables de los daños causados por los defectos de sus productos". Igualmente se pueden ver involucrados los proveedores de los materiales si a causa de la deficiente o mala calidad de los mismos se causan lesiones a las personas o daños a bienes diferentes al inmueble, en concordancia con lo preceptuado en el artículo 20 señalado. Para los efectos de esta responsabilidad, consumidor será toda persona que sufra daños, por lo que la noción de consumidor se extiende más allá de la misma definición de la Ley i480 de 20 i r. El caso reciente del edificio Space, en Medellín, sirve para ilustrar la responsabilidad por inmuebles defectuosos, pues debido a deficiencias en la construcción del inmueble el edificio colapsó, con el saldo trágico de doce personas muertas y cientos de personas perjudicadas por la pérdida de su vivienda. Cabe anotar que las decisiones administrativas y jurisdiccionales que a la fecha se han proferido por este caso no involucran la responsabilidad por producto defectuoso del Estatuto del Consumidor.

Así que, siguiendo lo que dice la norma, en la mayoría de los casos la responsabilidad se ocasionará por deficiencias en la construcción, y en menor medida por el diseño del inmueble. Nótese además que el número de personas involucradas en la responsabilidad derivada del daño ocasionado es mayor en materia de productos defectuosos, ya que, a diferencia de lo que ocurre en otros asuntos de protección al consumidor, además del constructor y el vendedor responderán todos los intervinientes en la gestión de la obra, incluidas eventualmente las autoridades si por omisión permitieron que se construyera la edificación.

Por tratarse de un régimen de responsabilidad objetiva, el consumidor víctima o sus herederos solamente tendrán que probar el defecto del bien inmueble y el nexo causal, operando una presunción de culpa en contra del constructor y los intervinientes en la obra, quienes solamente se exoneran de responsabilidad demostrando alguna de las cinco causales enumeradas en el artículo 22 de la Ley I 480 de 20 I I.

Hasta el momento, en el derecho colombiano no hay un antecedente jurisprudencial conocido en que se haya acudido a las normas de protección al consumidor por la responsabilidad de un inmueble defectuoso. Para finalizar se subraya que la responsabilidad por bien inmueble defectuoso no tiene regulación especial y se le aplica el régimen general contemplado en el Estatuto de

40 Tamayo Jaramillo, J. "La responsabilidad civil en el nuevo Estatuto del Consumidor", en Derecho del consumo, problemáticas actuales, J. M. Gual Acosta y J. C. Villalba Cuéllar (dirs.), Bogotá, Ibáñez, 2013, 662. 
Protección al Consumidor, así como la doctrina general sobre el tema, por lo que en lo que atañe a los objetivos de este artículo basta hacer esta referencia.

El aspecto que sí se ha ampliado en su tratamiento legal es el atinente al régimen preventivo, pues el tema se sensibilizó con ocasión del incidente del edificio Space, y la Ley I 796 de 20 I 6 está encaminada, entre otros aspectos, a fortalecer la seguridad de las edificaciones (arts. 3 a 7 ).

\section{Conclusiones}

El consumidor inmobiliario en Colombia cuenta con un marco legal de protección, al menos teórico, que le permite hacer valer sus derechos en caso de que se vean vulnerados, el cual se ha ido ampliando de manera paulatina y entra a jugar un rol protector de manera paralela a las normas del derecho común.

Este marco legal está constituido por normas generales de protección al consumidor, como la Ley I480 de 20 i y y el Decreto 735 de 2013, reglamentario del tema de garantía. De otro lado, se encuentran las normas que rigen el ámbito de la construcción, ya sean nacionales o locales, las cuales cumplen una función indirecta de protección al consumidor, por vía preventiva, al garantizar la seguridad de los inmuebles, y por vía sancionatoria administrativa, por los defectos que presentan los inmuebles.

La protección al consumidor inmobiliario en la etapa precontractual adquiere suma importancia porque este se ve inmerso en la celebración de actos jurídicos, ya sean cartas de separación o facturas de preventa, cartas de adhesión a una fiducia inmobiliaria, contrato de promesa de compraventa, entre otros; todos ellos de adhesión, lo cual implica un alto riesgo de que en dichos actos o contratos se incurra en desequilibrios contractuales o exoneraciones de responsabilidad que atenten contra los derechos de los consumidores inmobiliarios. Esta complejidad también implica que el deber de información a cargo del constructor o promotor inmobiliario se acentúe.

La publicidad engañosa es una práctica recurrente en la promoción y oferta de proyectos inmobiliarios, y los casos más frecuentes se presentan por la imprecisión de la información brindada a los consumidores frente a aspectos como área comprendida por el inmueble, características y dotación de los mismos, ya sea en áreas privadas o en áreas comunes. Así mismo es frecuente el cambio no informado de condiciones contractuales y características de los proyectos inmobiliarios.

La garantía por calidad e idoneidad de inmuebles nuevos tiene matices propios en el derecho de la protección al consumidor que conviven con otras normas del derecho común destinadas también a brindar remedios contractuales al consumidor inmobiliario, por lo cual se puede afirmar que este cuenta con una pluralidad de acciones a su favor.

La sic no es competente para imponer sanciones administrativas con ocasión de la garantía de los inmuebles, esta competencia la tienen las alcaldías 
municipales, aunque la sic sí conserva competencia en los demás aspectos de protección al consumidor inmobiliario.

La Secretaría del Hábitat en Bogotá, en lo que respecta a lo estudiado en este artículo, ejerce una función importante de protección al consumidor inmobiliario de manera indirecta, ya que lo hace con fundamento en otra serie de normas que no son las de protección al consumidor, lo cual es válido. No obstante, su función coercitiva a través de multas se puede ver opacada por los montos establecidos por la normatividad que regula este aspecto, a saber, el Decreto Ley 26 Io de i979 y el Decreto o 78 de I987, por lo que es necesario que esta normatividad se revise para adecuarla a las necesidades del contexto. Se ha observado que, sobre todo en casos de afectaciones graves o gravísimas a bienes comunes de una copropiedad, la multa impuesta no es disuasiva.

En materia de responsabilidad por inmuebles defectuosos el consumidor inmobiliario está protegido preventivamente por una serie de normas que hoy en día regulan la seguridad y calidad de los inmuebles nuevos. En cuanto a los daños sufridos con ocasión de inmuebles defectuosos se aplica el régimen general contenido en el Estatuto de Protección al Consumidor en concordancia con las normas generales de la responsabilidad civil.

\section{Bibliografía}

Ariza, A. "Contratación inmobiliaria y defensa del consumidor", La reforma al régimen de defensa del consumidor por Ley 26.36I, Ariel Ariza (coord.), Buenos Aires, Abeledo-Perrot, 2009.

Cañizares Laso, A. (coord.). Cláusulas abusivas en la contratación inmobiliaria, Madrid, Tecnos, 2006.

González Carrasco, C. La contratación inmobiliaria con consumidores, Centro de Estudios de Consumo y Universidad Castilla-La Mancha, disponible en: https://www.uclm.es/centro/cesco/pdf/comentarios/6.pdf

Gual Acosta, J. M. "El control sobre cláusulas abusivas un régimen en evolución”, Revista IUSTA, n. ${ }^{\circ}$ 30, enero-junio de 2009.

Gual Acosta y Villalba Cuéllar (dirs.), Derecho del consumo, problemáticas actuales, Bogotá, Ibáñez, 2013.

Hernández, C. A. y D. Esborraz. "Las cláusulas abusivas en la contratación inmobiliaria", Colección de derecho privado, Abuso del derecho, Revista de la Facultad de Derecho y Ciencias Sociales de Rosario, 2006, disponible en: http://www.saij. gob.ar/doctrina/dasfo60078-hernandez-las_clausulas_abusivas_en.htm 
JazAPE, B. "El deber de información”, Manual de derecho del consumidor, Buenos Aires, Rusconi Dante, Abeledo-Perrot, 2009.

Legis Editorial. Aspectos conceptuales del negocio fiduciario en Colombia, Bogotá, 2015 .

Lorenzetti, R. L. Consumidores, Buenos Aires, Rubinzal-Culzoni, 2009.

Miranda, L. M. y M. Paniagua Zurera. "La protección de los consumidores y usuarios en la fase previa de la contratación: la tutela de la libertad negocial”, Derecho (privado) de los consumidores, L. Miranda y J. Pagador (coords.), Madrid, Marcial Pons, 2012.

Ossa Gómez, D. "La responsabilidad civil en el Estatuto del Consumidor. Las garantías de calidad, idoneidad, y seguridad de los productos", Revista Estudios de Derecho, Lxx, 20I 3, I 56, 237-264.

Rodríguez Azuero, S. Contratos bancarios, Bogotá, Legis, 20 I I.

Rodríguez Azuero, S. Negocios fiduciarios, su significación en América Latina, Bogotá, Legis, 2005.

Tamayo Jaramillo, J. y D. Ossa Gómez. "La responsabilidad civil y los seguros en la construcción de inmuebles: una aproximación comparativa entre el derecho colombiano y francés”, RIS, 43, 2015, I 7 I-I9I.

Tamayo Jaramillo, J. "La responsabilidad civil en el nuevo Estatuto del Consumidor", Derecho del consumo, problemáticas actuales, J. M. Gual Acosta y J. C. Villalba Cuéllar (dirs.), Bogotá, Ibáñez, 20 I 3.

Villalba Cuéllar, J. C. Introducción al derecho del consumo, Bogotá, Universidad Militar Nueva Granada, 20 I 2.

Villalba Cuéllar, J. C. "La responsabilidad del productor por garantías de bienes y servicios en el derecho colombiano", Prolegómenos. Derechos y Valores, enero-junio de $2013,45^{-67}$.

Universidad Sergio Arboleda, Superintendencia de Industria y Comercio y Red Nacional de Protección al Consumidor. Documento técnico: análisis de las problemáticas de los consumidores del sector de la construcción, Bogotá, 20 I6. 


\section{Superintendencia de Industria y Comercio}

Resolución 13385 del 30 de abril de 2008.

Resolución 9I49 del 20 de febrero de 2014.

Resolución 61242 del ro de octubre de 2014.

Resolución I 5420 del 25 de marzo de 20 I I.

\section{Secretaría del Hábitat}

Resolución 2 I 83 del 20 de noviembre de 20 I 2.

Resolución 2 I 82 del 20 de noviembre de 2012.

Resolución 2069 del 9 de noviembre de 20 I 2.

Resolución I987 del 24 de octubre de 2012.

Resolución I8I8 del 20 de septiembre de 20 I 2.

Resolución 2 I 70 del I9 de noviembre de 20 I 2.

Resolución 2 I62 del I9 de noviembre de 2012.

Resolución 2 I I 5 del I4 de noviembre de 20 I 2.

Resolución 2073 del 9 de noviembre de 2012.

Resolución 2202 del 2 I de noviembre de 2012.

Resolución 682 del 2 I de abril de 2013.

Resolución 7 IO de abril de 2013.

Resolución 7I I del ro de abril de 2013.

Resolución 879 del 2 I de mayo de 2013.

Resolución 88I del 22 de mayo de 2013. 
Resolución 886 del 23 de mayo de 20 I3.

Resolución 89i del 27 de mayo de 20 r 3.

Resolución 892 del 27 de mayo de 2013.

Resolución 893 del 27 de mayo de 2013.

Resolución 904 del 29 de mayo de 2013.

Resolución 905 del 30 de mayo de 2013.

Resolución ro8 del 7 de febrero de 20 I4.

Resolución r 26 del I 2 de febrero de 20 I 4.

Resolución I 83 del I 8 de febrero de 20 I 4.

Resolución I92 del i9 de febrero de 20 I4.

Resolución I99 del 2 I de febrero de 2014.

Resolución 200 del 24 de febrero de 2014.

Resolución 204 del 24 de febrero de 2014.

Resolución 2 I 4 del 25 de febrero de 2014.

Resolución 2 I 7 del 25 de febrero de 20 I 4 .

\section{Sentencias}

Corte Suprema de Justicia, Sala de Casación Civil, 5 de junio de 2009, exp. C-o80or 3 I03006 I 993-08770-or, M.P.: Jaime Arrubla Paucar.

Corte Suprema de Justicia, Sala de Casación Civil, 7 de octubre de 20i6, SCi4426-2016, rad. 41001 3 I030042007000790 I, M.P.: Ariel Salazar Ramírez.

Corte Suprema de Justicia, Sala de Casación Civil, I de noviembre de 20 I I, exp. I IOOI-3 IO3-OI 8-2002-00292-OI, M.P.: Ruth Marina Díaz Rueda. 
Tribunal Superior de Bogotá, rad. 2014-I62-47 02, acción de protección al consumidor de Andrea Henao y otros contra Alsacia Constructora S.A., Lérida Constructora S.A., Gonelas S.A.S. en liquidación y Calamar cDo s.A.s. 